\title{
Penatalaksanaan Kolesteatom Eksterna dengan Timpanomastoidektomi Dinding Runtuh
}

\author{
Rimelda Aquinas, Yan Edward
}

\begin{abstract}
Abstrak
Kolesteatom adalah massa kistik dengan epitel skuamosa, berisi keratin yang proliferatif dan bisa menyebabkan terjadinya destruksi tulang. Kolesteatom eksterna adalah kolesteatom yang terdapat di kanalis akustikus eksternus. Timpanomastoidektomi dinding runtuh adalah tindakan operasi pada kasus kolesteatom eksterna untuk eradikasi kolesteatom, mencegah terjadinya komplikasi dan mempertahankan pendengaran. Dilaporkan satu kasus kolesteatom eksterna pada wanita usia 21 tahun yang meluas ke kavum mastoid dan menimbulkan defek pada kanalis akustikus eksternus. Pada pasien dilakukan tindakan timpanomastoidektomi dinding runtuh telinga kiri. Operasi timpanomastoidektomi dinding runtuh yang dilakukan pada kasus kolesteatom eksterna dengan perluasan ke kavum mastoid memberikan hasil yang baik. Kontrol secara rutin diperlukan untuk mencegah terjadinya rekurensi.
\end{abstract}

Kata kunci: kolesteatom, kolesteatom eksterna, timpanomastoidektomi dinding runtuh

\begin{abstract}
Cholesteatom is a cystic mass lined with stratified squamous epithelium containing proliferative keratin with bony destruction. External ear canal cholesteatom is cholesteatom located in external auditory canal. Canal wall down tympanoplasty surgery is procedure to complete eradication of cholesteatom, preventing complications and preserve hearing function. It was reported a case of external ear canal cholesteatom, extended to cavum mastoid and cause defect to external ear canal, in 21 year old woman, that performed canal wall down tympanoplasty on left ear. Canal wall down tympanoplasty can be performed in case when external ear canal cholesteatom extended to the air cell mastoid. Reguler follow up is important to prevent recurrence condition.
\end{abstract}

Keywords: cholesteatom, external ear canal cholesteatom, canal wall down mastoidectomy

Affiliasi penulis: Bagian THT-KL, Fakultas Kedokteran, Universitas Andalas, Padang, Indoenesia

Korespondensi: Rimelda Aquinas. Email: rimelaquinas@gmail.com Telp:+62 81277723068

\section{PENDAHULUAN}

Kolesteatom eksterna merupakan penyakit yang jarang ditemukan. Pada populasi umum insidensinya yaitu 0,15 kasus/100.000 individu. Estimasi rerata insidensinya adalah $1,2-3,7 / 1000$ pasien otologi. ${ }^{1,2}$ Rerata distribusi usia yaitu 53 tahun (range usia 33 tahun hingga 82 tahun). ${ }^{3}$ Insidensinya 60 kali lebih sedikit dibandingkan dengan kasus kolesteatom pada telinga tengah. ${ }^{4}$ Penelitian lebih lanjut menunjukkan kolesteatom eksterna juga terjadi pada usia muda. Berdasarkan jenis kelamin, kolesteatom eksterna lebih sering terjadi pada wanita dibandingkan pria, dengan rasio 13:12 3

Kolesteatom eksterna terdiri dari jaringan deskuamasi dan erosi tulang. ${ }^{5}$ Dubach et al (2010) menggambarkan kolesteatom eksterna sebagai penumpukan epidermal di liang telinga ${ }^{4}$. Menurut $\mathrm{Ho}$ et al (2017), kolesteatom eksterna adalah lesi yang berisi epitel skuamosa berlapis yang mengandung keratin proliferatif, bisa menyebabkan erosi tulang. ${ }^{6}$

\section{Patofisiologi}

Terdapat 2 teori mengenai patofosiologi kolesteatom eksterna, yaitu teori trauma minor pada kulit liang telinga, misalnya akibat penggunaan cotton 
bud, kuku atau serumen yang keras yang menimbulkan reaksi inflamasi dan ulserasi yang akan menyebabkan terjadinya periosteitis dan nekrosis pada tulang di liang telinga. Selanjutnya akan terjadi invasi dan proliferasi epitel skuamosa yang proses akhirnya adalah terbentuknya kolesteatom di daerah tersebut. Proses invasi epitel skuamosa menyebabkan terjadinya nyeri tumpul pada pasien. Proses penuaan epitel kulit liang telinga akan mengakibatkan aliran darah di tempat tersebut berkurang, jaringan kulit mengalami hipoksia sehingga proses normal migrasi epitel menurun. Terjadi penumpukan sel epitel yang akan menyebabkan terbentuknya kolesteatom. ${ }^{7}$ Kolesteatom eksterna paling sering terjadi pada dinding inferior liang telinga (80\%) karena dinding inferior merupakan daerah dengan migrasi epitel tertinggi namun miskin akan pembuluh darah. Lokasi tersering lainnya, yaitu postero inferior (40\%), inferior $(30 \%)$, posterior $(20 \%)$ dan posterior- inferior- anterior $(10 \%){ }^{6}$

\section{Klasifikasi}

Beberapa klasifikasi kolesteatom eksterna, yaitu:

1. Klasifikasi Shin

Klasifikasi Shin berdasarkan gambaran Computed Tomography (CT) scan mastoid (Tabel 1 dan Gambar 1). ${ }^{8}$

Tabel 1. Klasifikasi berdasarkan CT scan mastoid ${ }^{8}$

\begin{tabular}{lll}
\hline Derajat & Definisi & Tata Laksana \\
\hline I & $\begin{array}{l}\text { Terbatas pada } \\
\text { *KAE }\end{array}$ & $\begin{array}{l}\text { Konservatif dan } \\
\text { kanaloplasti }\end{array}$ \\
II & Pada *KAE, & Kanaloplasti dan \\
& menginvasi & timpanoplasti \\
& membran timpani & \\
& dan telinga tengah & \\
III & Terdapat defek & Kanaloplasti + \\
& pada *KAE dan & mastoidektomi + \\
& melibatkan air cell & timpanoplasti + \\
& mastoid & rekonstruksi *KAE \\
& & \\
IV & Invasi lesi melewati & Dengan berbagai \\
& tulang temporal & pendekatan \\
\hline
\end{tabular}

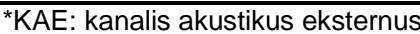

\section{Klasifikasi Naim ${ }^{6}$}

Klasifikasi Naim dibuat berdasarkan bukti klinis, patologi dan radiologi (Tabel 2).

Tabel 2. Klasifikasi Naim ${ }^{6}$

\begin{tabular}{lll}
\hline No & Stadium & Derajat \\
\hline 1 & I & Hiperplasia dan hiperemis epitel \\
& KAE* \\
& Tidak terdapat destruksi tulang \\
& pada KAE* Terdapat akumulasi \\
& debris keratin. \\
& & Permukaan epitel intak \\
& Ekstravasasi defek epitel dengan \\
& keterlibatan tulang \\
& Destruksi struktur tulang pada \\
& kanal dengan sekuester tulang \\
& III & Destruksi struktur anatomi \\
& Subkelas M: mastoid \\
& Subkelas S: tulang tengkorak \\
& dengan sinus sigmoid \\
& Subkelas J: temporo mandibular \\
& joint \\
& Subkelas F: nervus fasialis \\
&
\end{tabular}

\section{Klasifikasi Tos}

Klasifikasi Tos terdiri dari kolesteatom eksterna primer, kolesteatoma eksterna sekunder dan kolesteatom yang berkaitan dengan atresia kongenital pada liang telinga. Kolestetoma eksterna primer atau kolesteatom tipe spontan terjadi karena terganggunya proses migrasi epitel kulit liang telinga, misalnya terjadi pada orang tua. ${ }^{9,10}$ Kolesteatom eksterna sekunder bisa terjadi karena komplikasi trauma terhadap telinga luar atau komplikasi tindakan operasi di telinga tengah. Laserasi pada telinga luar mengakibatkan sel epitel menumpuk sehingga terbentuk kolesteatom pada telinga luar. Lokasi kolesteatom tersebut tergantung tempat lesi primer. ${ }^{11}$ 


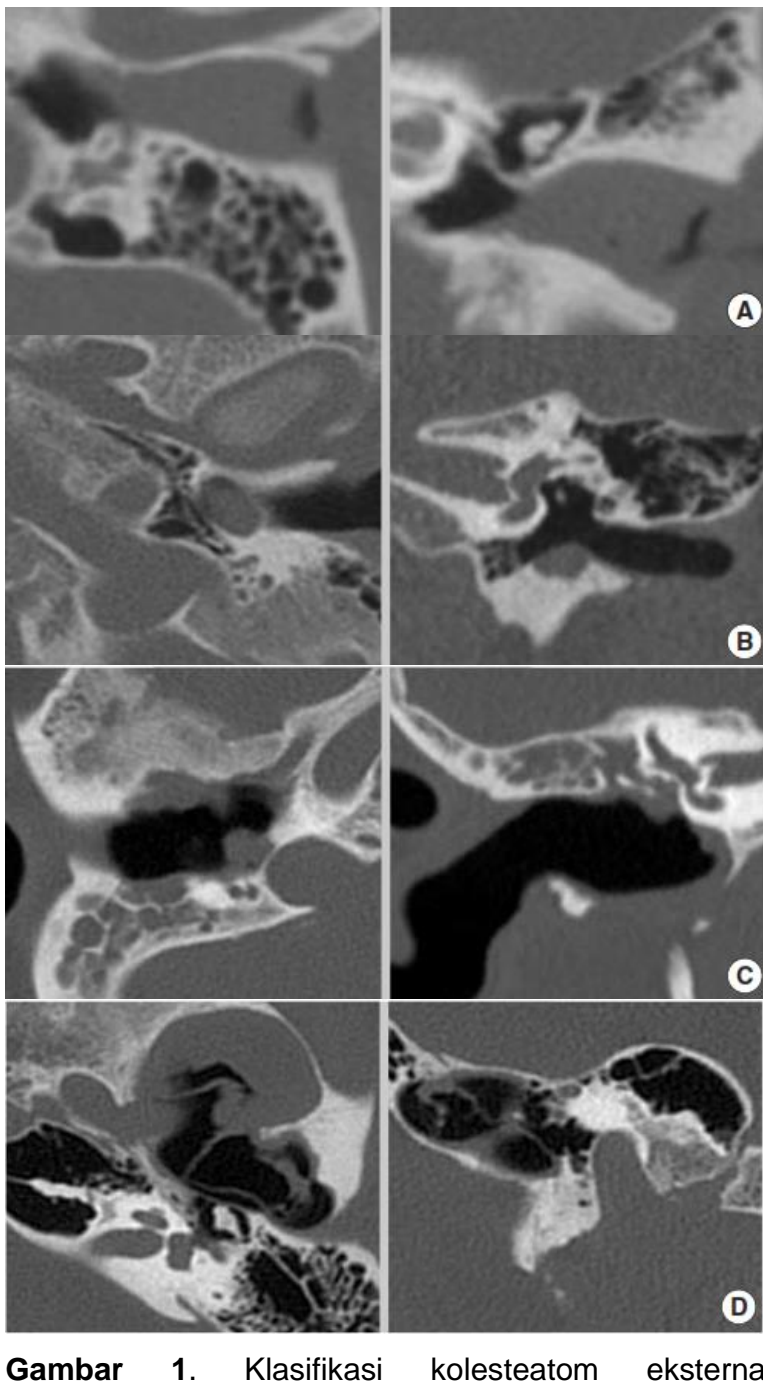

Gambar 1. Klasifikasi kolesteatom eksterna berdasarkan CT scan mastoid. Stadium I (A), stadium II (B), stadium III (C), stadium IV (D). ${ }^{8}$

\section{Diagnosis}

Pada anamnesis didapatkan keluhan telinga berair, telinga terasa gatal, penurunan pendengaran, nyeri telinga, telinga terasa penuh dan telinga berdenging. Gejala klinis pada kolesteatom eksterna antara lain, otalgia, gangguan pendengaran, otore dan tinitus. ${ }^{12}$ Otalgia yang terjadi karena invasi lokal epitel skuamosa ke struktur tulang. ${ }^{13}$ Pada audiometri didapatkan hasil normal hingga tuli konduksi derajat sedang. ${ }^{14}$

Diagnosis banding kolesteatom eksterna antara lain, keratosis obturan yaitu kondisi dimana terdapat akumulasi deskuamasi keratin pada liang telinga. Keratosis obturan merupakan akumulasi plak deskuamasi keratin di liang telinga luar (tabel 3). Dengan diangkatnya deskuamasi keratin akan memperlihatkan liang telinga yang sempit, tampak hiperemis dengan jaringan granulasi. ${ }^{5}$ Diagnosis banding lainnya, yaitu otitis eksterna maligna. Infeksi berat pada otitis eksterna maligna melibatkan kanalis akustikus eksternus dan jaringan lunak sekitarnya, bahkan melibatkan tulang tengkorak. Otitis eksterna maligna terjadi pada orang tua dengan diabetes militus. Pada banyak kasus disebabkan oleh Pseudomonas aeruginosa. Pasien biasanya mengeluhkan otalgia berat, otore, dan jaringan granulasi yang persisten sepanjang lantai kanalis akustikus eksternus. ${ }^{15,16}$ Pada pemeriksaan CT scan mastoid didapatkan densitas jaringan lunak yang asimetris pada kanalis akustikus eksternus, dengan atau tanpa perluasan ke jaringan sekitarnya. ${ }^{17}$

Tabel 3. Perbedaan keratosis obturan dan kolesteatom eksterna ${ }^{7}$

\begin{tabular}{lll}
\hline Karakteristik & $\begin{array}{l}\text { Keratosis } \\
\text { obturan }\end{array}$ & $\begin{array}{l}\text { Kolesteatom } \\
\text { eksterna }\end{array}$ \\
\hline $\begin{array}{l}\text { Usia } \\
\text { Penyakit terkait }\end{array}$ & $\begin{array}{l}\text { Muda } \\
\text { Sinusitis, } \\
\text { bronkiektasis }\end{array}$ & $\begin{array}{l}\text { Tua } \\
\text { Tidak ada }\end{array}$ \\
Nyeri & Akut, berat & Tumpul \\
Gangguan & Konduktif, sedang & Tidak ada \\
pendengaran & & \\
Lateralisasi & Bilateral & Unilateral \\
Erosi tulang & Sirkumferensial & Terlokalisasi \\
\hline
\end{tabular}

Pada pemeriksaan CT scan mastoid kolesteatom eksterna terlihat sebagai massa jaringan lunak di kanalis akustikus eksternus yang berhubungan dengan erosi tulang. Erosi tulang dengan pinggir rata mirip dengan kolesteatom pada telinga tengah. Erosi dapat juga terjadi dengan pinggir ireguler karena nekrosis tulang dan periosteitis. Dinding inferior dan anterior bisa terlibat. Penting untuk menilai keterlibatan telinga tengah, mastoid, kanalis fasialis dan tegmen timpani karena akan menentukan penatalaksanaan selanjutnya. ${ }^{5}$ Selain itu pada CT scan tampak adanya massa jaringan lunak dengan destruksi tulang pada dinding inferior liang telinga. ${ }^{6}$

Pada pemeriksaan histopatologi, kolesteatoma eksterna dibuktikan dengan adanya periosteitis yang terbatas pada area yang erosi, terjadi osteitis, tampak sekuester tulang dan jaringan yang terinflamasi. Sel 
epidermal ditemukan di sekitar tulang yang mengalami sekusterisasi. ${ }^{18}$ Tampak juga adanya epitel berkeratin dan epitel skuamosa bertingkat sehingga pada pemeriksaan histopatologi dapat membantu menyingkirkan diagnosis banding. ${ }^{19}$

\section{Penatalaksanaan}

Berbagai teknik operasi dilakukan pada kasus kolesteatom eksterna, dimana tujuan primer operasi adalah untuk eradikasi penyakit, preservasi struktur dan fungsi pembersihan spontan liang telinga serta fungsi pendengaran dan juga modifikasi anatomi kompartemen timpanomastoid sehingga bisa mencegah terjadinya rekurensi. Pada stadium awal, kolesteatoma eksterna tanpa destruksi tulang diobati secara konservatif. Pilahan utama penatalaksanaan adalah membersihkan debris keratin dan dipasang kassa dengan zalf kortikosteroid dan salisilat. Apabila tejadi keterlibatan tulang maka operasi diperlukan. Defek pada tulang diisi dengan tandur jaringan lunak, kartilago konka dan temporalis. Bila terjadi defek pada kavitas mastoid, dilakukan obliterasi dengan inferior based subcutis muscle periosteum flap yang diambil sepanjang tepi posterior insisi aurikula. Beberapa penulis menyarankan penggunaan perikondrium. Ho melaporkan penggunaan 2 teknik operasi untuk kolesteatom eksterna. Pertama kolesteatom eksterna dibersihkan sehingga pinggir epitel normal terlihat, diikuti dengan menghaluskan permukaan kontur tulang. Kedua, dilakukan pemasangan graft untuk menutup defek tulang dan kanalis akustikus eksternus diisi dengan gelfoam. teknik dilakukan untuk membersihkan kolesteatom dan merekonstruksi defek yaitu, setelah dilakukan eradikasi pada kolesteatom, dinding tulang yang ireguler dibor dengan menggunakan diamond dan dilakukan kanaloplasti dengan inferior pedicled soft tissue periosteal flap untuk mengobliterasi defek pada kanalis akustikus eksternus. Kemudian rekonstruksi disempurnakan dengan inferior pedicled soft tissue periosteal flap, fasia temporalis, full thickness skin graft, dan dipacking dengan busa agar (gelfoam) lapis demi lapis. ${ }^{6}$ Zanini et al menggunakan teknik radikal mastoidektomi dengan modifikasi dan dilakukannya meatoplasti yang luas sehingga dapat mengontrol hasil post operatif lebihbaik. ${ }^{5}$
Pada kolesteatom eksterna derajat IV berdasarkan klasifikasi Naim, dimana terjadi keterlibatan mastoid, dilakukan operasi timpanimastoidektomi dinding runtuh. Indikasi lain dilakukan timpanomastoidektomi dinding runtuh, yaitu rekurensi setelah dilakukan timpanomastoidektomi dinding utuh, kolesteatom bilateral, sindrom down dan celah palatum, only hearing ear, fistula labirin yang luas, tumor jinak yang melibatkan telinga tengah, tumor ganas yang melibatkan kanalis akustikus eksternus, pada dead ear, sensory neural hearing loss yang berat, erosi dinding kanal yang luas, kolesteatom bilateral, konsisi umum yang jelek, usia lanjut, kesulitan dalam follow up, keterlibatan sinus sigmoid atau tegmen plate yang sangat rendah. ${ }^{20,21}$

\section{Follow Up}

Pencegahan rekurensi, selain eradikasi komplit juga diperlukan follow up teratur. Penelitian Yurttas et al (2015) menyebutkan follow up diperlukan sekitar 6 bulan hingga 30 bulan. ${ }^{22}$ Spronsen dan Geerse (2014) menyebutkan bahwa rerata follow up diperlukan sekitar 18 bulan. ${ }^{23}$

\section{KASUS}

Seorang wanita usia 21 tahun datang ke poliklinik THT-KL Dr. M. Djamil Padang pada tanggal 17 Januari 2018 dengan keluhan utama telinga kiri berair sejak 3 bulan sebelum masuk rumah sakit. Cairan yang keluar berwarna kekuningan dan berbau busuk, tidak bercampur darah. Riwayat telinga kiri berair sebelumnya tidak ada. Penurunan pendengaran pada teling kiri ada sejak 6 bulan sebelum masuk rumah sakit.

Riwayat sering mengorek telinga dengan cotton bud ada. Telinga kiri kadang terasa gatal. Bengkak di belakang telinga tidak ada. Riwayat pusing berputar tidak ada. Wajah mencong tidak ada. Penurunan kesadaran tidak ada. Riwayat trauma pada kepala atau telinga tidak ada, riwayat operasi telinga tidak ada. Riwayat penyakit diabetes militus dan riwayat merokok tidak ada. Riwayat nyeri kepala hebat, disertai mual dan muntah tidak ada.

Pada pemeriksaan fisik didapatkan status umum dalam keadaan baik, kesadaran komposmentis dan tidak demam. Pada status lokalis THT didapatkan 
telinga kanan: daun telinga tidak ada kelainan, tidak terdapat nyeri tekan tragus dan nyeri tarik daun telinga, tidak terdapat bengkak di retroaurikuler. Liang telinga lapang, membran timpani utuh, terdapat reflek cahaya.

Pada pemeriksaan telinga kiri; daun telinga tidak ada kelainan, tidak terdapat nyeri tekan tragus dan nyeri tarik daun telinga, tidak terdapat bengkak di retroaurikuler. Liang telinga sempit, membran timpani tertutup kolesteatom dan terdapat sekret mukopurulen (Gambar 2). Pada pemeriksaan hidung dan tenggorok dalam batas normal. Pada leher tidak ditemukan adanya pembesaran kelenjar getah bening. Pada pasien ditegakkan diagnosis kerja suspek kolesteatom eksterna telinga kiri, dengan diagnosis banding suspek OMSK telinga kiri dengan kolesteatom.

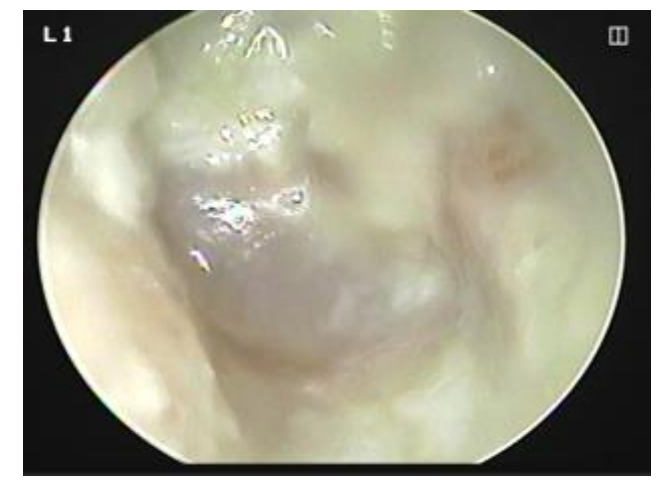

Gambar 2. Otoskopi telinga kiri sebelum operasi

Pada pemeriksaan penala 5 frekuensi didapatkan kesan tuli konduksi telinga kiri. Pada pemeriksaan fungsi keseimbangan dan saraf fasialis tidak ditemukan kelainan. Pemeriksaan audiometr didapatkan telinga kanan normal dengan ambang dengar $10 \mathrm{~dB}$ dan telinga kiri tuli konduksi derajat ringan dengan ambang dengar $30 \mathrm{~dB}$ (Gambar 3).

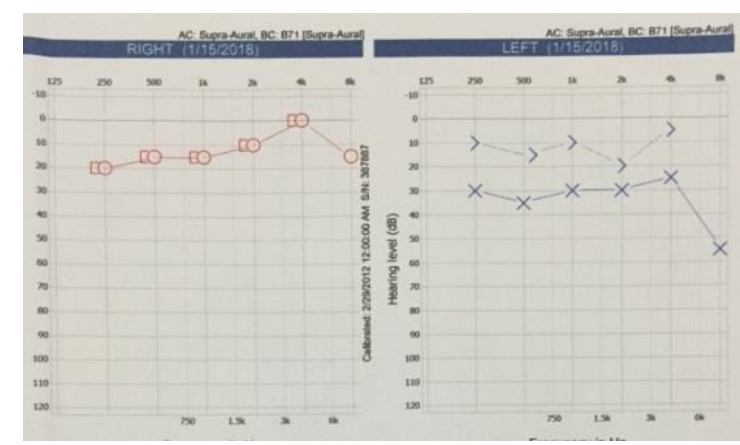

Gambar 3. Audiometri telinga sebelum operasi
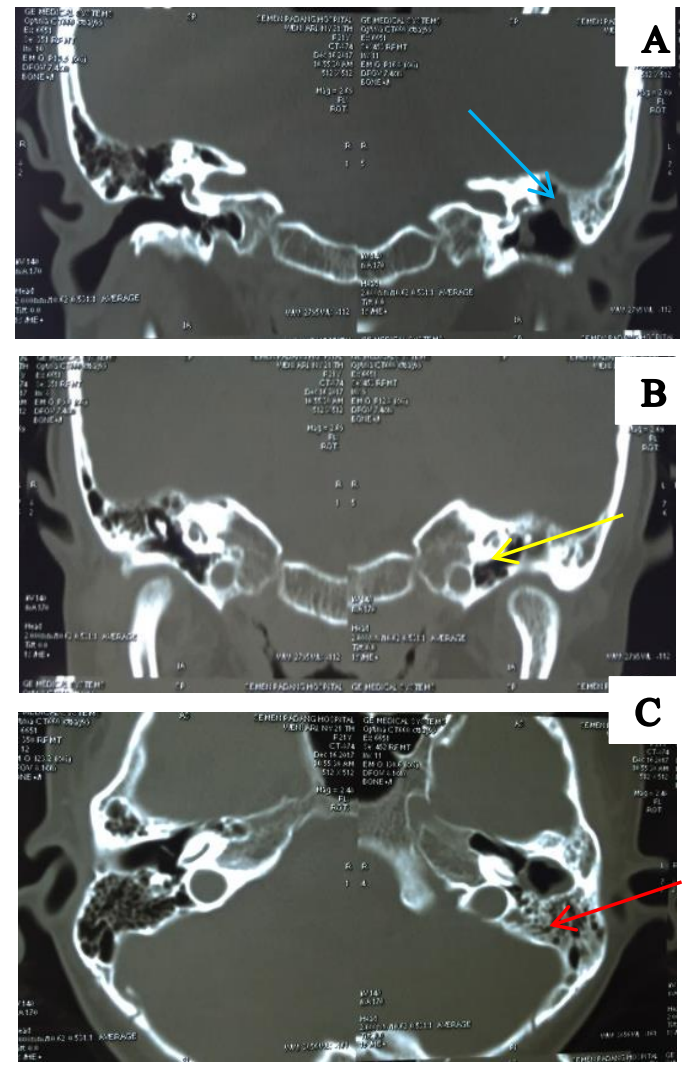

Gambar 4. CT Scan Mastoid potongan coronal, skutum tumpul, destruksi dinding posterior (A). CT scan mastoid potongan coronal, osikel tervisualisasi sebagian, tidak intak (B). CT Scan mastoid potongan axial, tampak perselubungan pada antrum dan periantrum mastoid sinistra $(\mathrm{C})$.

Pada pemeriksaan CT scan mastoid sebelah kanan didapatkan kesan dalam batas normal. CT scan mastoid sebelah kiri tampak pneumatisasi air cell mastoid berkurang. Liang telinga terbuka, membran timpani tidak tervisualisasi. Skutum tumpul, meatus akustikus internus terbuka, tegmen mastoid dan sinus sigmoid intak. Terdapat destruksi dinding posterior. Tampak perselubungan pada antrum dan periantrum mastoid sinistra. Tulang pendengaran tervisualisasi sebagian, tidak intak. Tegmen timpani intak. Koklea dan kanalis semi sirkularis tidak tampak kelainan (Gambar 4). Diagnosis kerja pada pasien yaitu suspek kolesteatom eksterna telinga kiri. Dilakukan kultur sensitivitas. Pasien diberikan terapi medikamentosa dan dipersiapkan untuk operasi timpanomastoidektomi dinding runtuh. Hasil pemeriksaan darah dalam batas normal. Hasil kultur didapatkan Pseudomonas aeruginosa dan diberikan seftazidim. 


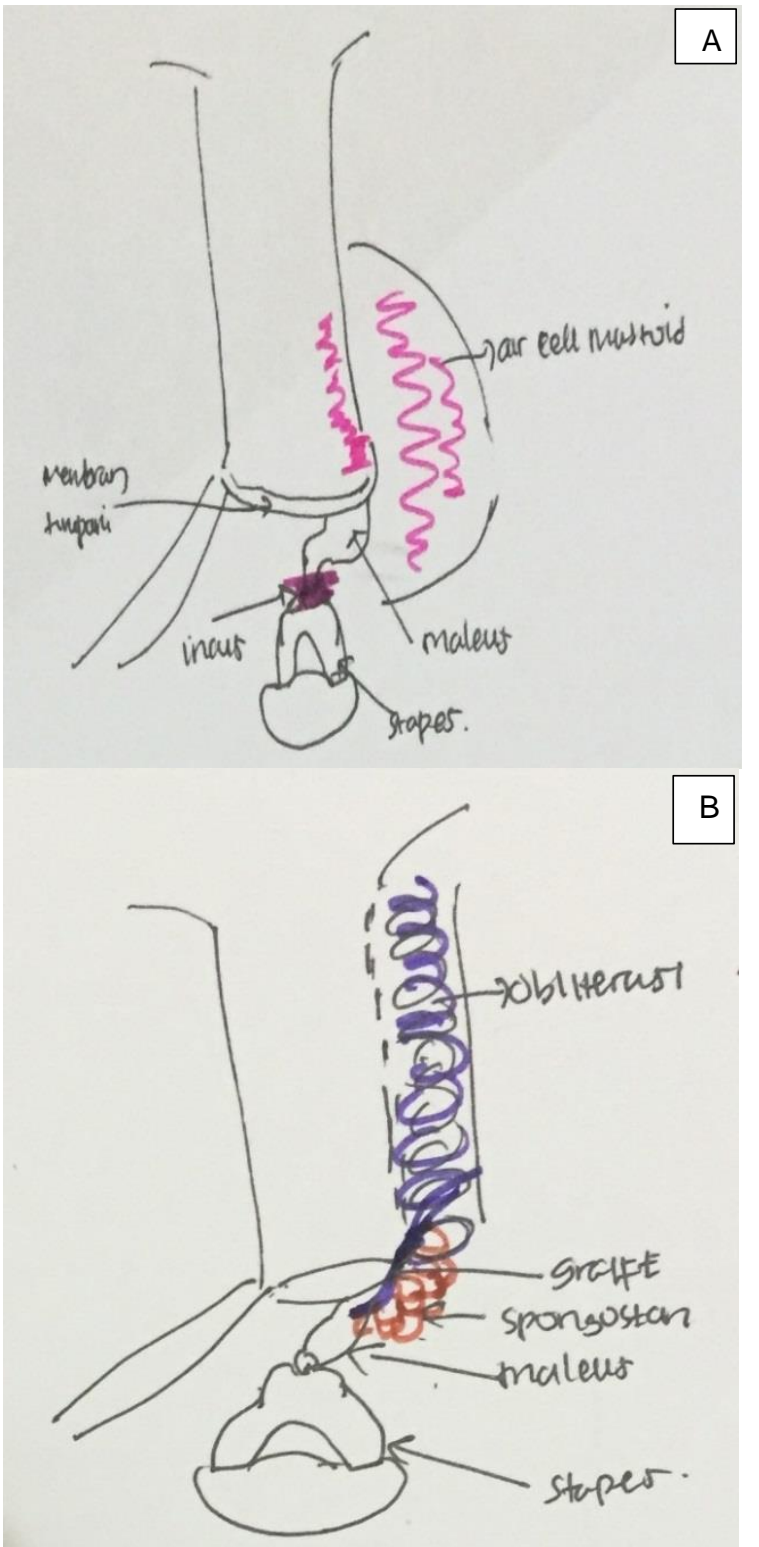

Gambar 5. Sketsa tindakan timpanomastoidektomi dinding runtuh (Edward Y; gambar tidak dipublikasikan dan merupakan data personal)

Pada operasi timpanomastoidektomi dinding runtuh, didapatkan kolesteatom mendestruksi dinding posterior dan inferior liang telinga, inkus dan air cell mastoid (gambar 5A, warna merah muda). Membran timpani utuh dan terdorong ke arah promontorium, atelektasis. Inkus diangkat dan membran timpani dipisahkan dari promontorium. Dilakukan obliterasi dan pemasangan graft dari fasia temporalis profunda secara underlay dan difiksasi dengan spongostan (gambar 5B, warna ungu dan oranye). Hasil pemeriksaan histopatologi sesuai untuk gambaran kolesteatom (Gambar 6).
Bulan kedua pasien kontrol, tampak sekret minimal pada liang telinga. Pada bulan ketiga, tampak graft tumbuh, liang telinga sedikit basah dan tidak ada tanda-tanda infeksi dengan kavitas yang tidak terlalu luas (Gambar 7). Audiometri menunjukkan adanya telinga kiri tuli konduksi derajat sedang dengan ambang dengar 53,75 dB (Gambar 8).

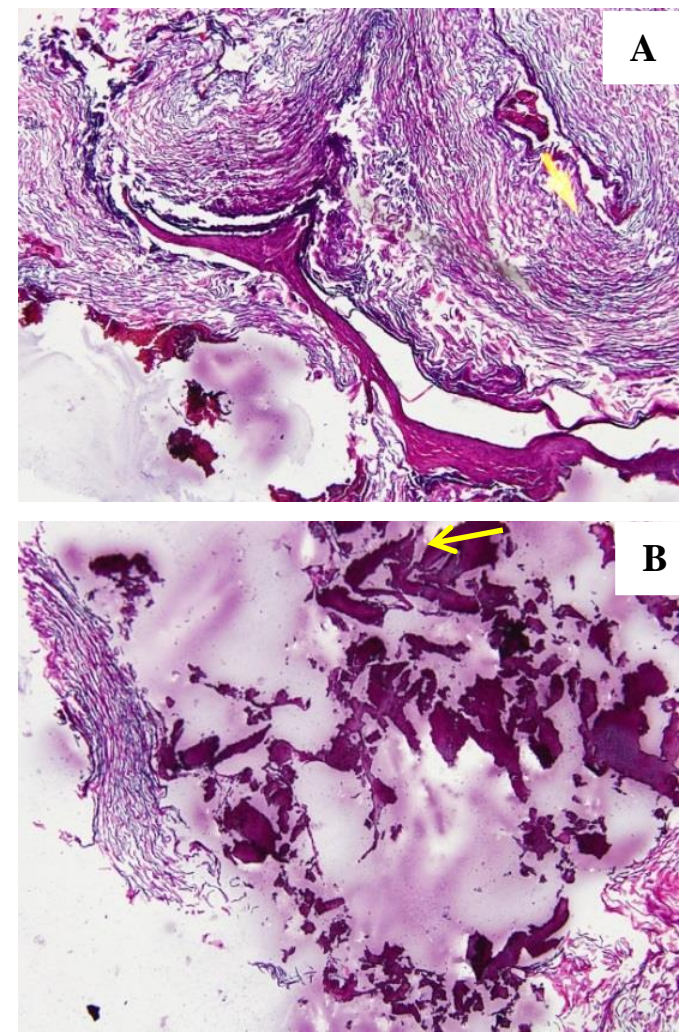

Gambar 6. Histopatologi kolesteatom eksterna, tampak epitel berlapis gepeng dengan massa berkeratin di bawahnya (A) dan tampak sequester tulang (B)

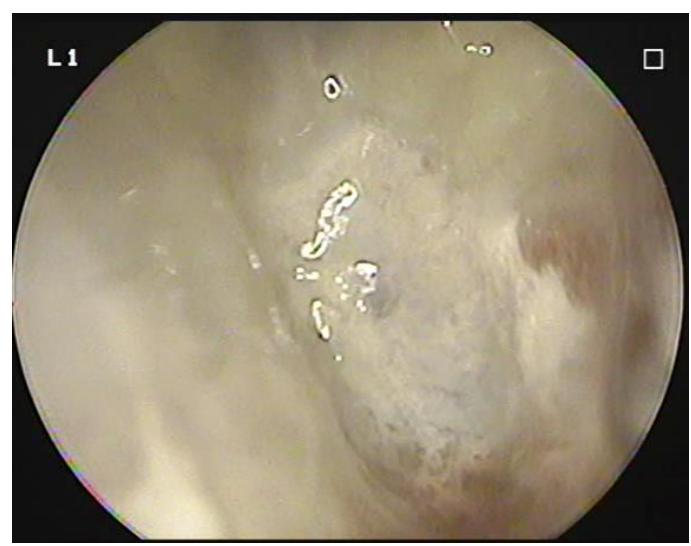

Gambar 7. Pemeriksaan otoskopi telinga kiri bulan ketiga post operasi 


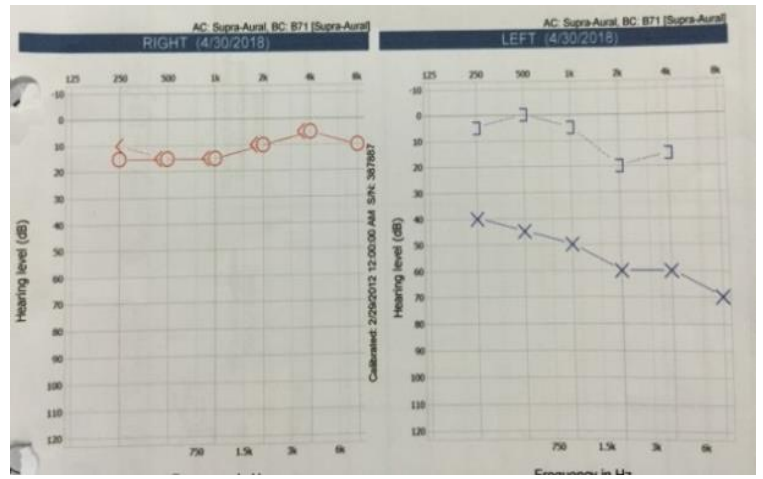

Gambar 8. Audiometri bulan ke-3 post operasi

\section{PEMBAHASAN}

Suatu kasus wanita 21 tahun dengan diagnosis kolesteatom eksterna pada telinga kiri. Hal ini sesuai dengan penelitian Owen et al bahwa kolesteatom eksterna lebih sering terjadi pada perempuan dibandingkan laki-laki dengan perbandingan 13:12 dan pada usia tua dengan rerata usia 57 tahun (range usia 33 tahun hingga 82 tahun) namun kolesteatom eksterna juga bisa terjadi pada usia muda. ${ }^{3}$ Gejala klinis pada pasien didapatkan otore. Berdasarkan penelitian Dubach et al (2010) didapatkan gejala klinis tersering pada kolesteatom eksterna adalah otalgia, otore, oklusi, gangguan pendengaran, telinga terasa penuh, dan telinga terasa gatal. ${ }^{4}$

Pemeriksaan otoskopi cukup sulit membedakan kolesteatoma eksterna dengan suatu proses inflamasi, infeksi, atau suatu tumor liang telinga. Menurut Chawla et al (2015) pada pemeriksaan otoskopi tampak adanya serpihan putih pada kanalis akustikus eksternus yang mencerminkan suatu debris keratin. ${ }^{24}$ Pemeriksaan otoskopi pada pasien didapatkan kolesteatom menutupi sebagian membran timpani sehingga membran timpani tidak bisa dinilai secara keseluruhan. Kemungkinan adanya perforasi di atik belum bisa disingkirkan. ${ }^{25}$ Pasien didiagnosis banding dengan Suspek OMSK AS dengan kolesteatom karena dari gejala klinis dan pemeriksaan fisik belum dapat disingkirkan, yaitu terdapatnya cairan yang keluar dari telinga kiri berwarna kekuningan yang berbau busuk sejak 3 bulan sebelum masuk rumah sakit dan membran timpani yang belum bisa dinilai secara keseluruhan.

Audimetri pada pasien didapatkan tuli konduksi derajat ringan telinga kiri dengan ambang dengar 30
dB. Ini sejalan dengan penelitian Aswarni et al (2016) bahwa gangguan pendengaran pada kolesteatom eksterna tuli konduksi derajat ringan hingga derajat sedang. ${ }^{10}$

Hasil pemeriksaan CT scan tampak ada perselubungan di mastoid dengan destruksi tulang pendengaran. Hal ini sejalan dengan penelitian yang dilakukan oleh Zanini et al bahwa terjadi invasi kolesteatom eksterna ke air cell mastoid dan osikel dengan membran timpani yang utuh. ${ }^{5}$ Ho et al (2017) meyebutkan bahwa gambaran CT scan mastoid pada kolesteatom eksterna yaitu tampakmassa jaringan lunak dengan destruksi tulang pada inferior KAE. ${ }^{6}$

Pemeriksaaan kultur sensitivitas didapatkan kuman penyebab adalah Pseudomonas aereginosa yang merupakan kuman patogen oportunistik di dalam tubuh. Kuman ini menginfeksi tubuh disaat tubuh dalam kondisi lemah. Antibiotik yang peka adalah cefotaksim, ceftazidim, dan meropenem. Kuman terbanyak yang ditemukan dalam infeksi telinga dengan kolesteatom adalah Pseudomonas sp, Staphylococcus, Streptococcus, dan bakteri anaerob, seperti Peptostreptococcus spp, Prevotella spp, Porphyromonas spp, Bacteroides spp, dan Fusobacterium spp. ${ }^{26,27}$

Pada pasien telah dilakukan operasi timpani mastoidektomi dinding runtuh pada telinga kiri. Pemilihan operasi seperti yang direkomendasikan oleh Shin bahwa pada stadium III direkomendasikan prosedur kanaloplasti + mastoidektomi \pm timpanoplasti \pm rekonstruksi pada KAE. Pemilihan operasi ini karena kolesteatom selain mengenai liang telinga luar, juga mendestruksi mastoid, dinding posterior liang telinga dan tulang pendengaran. Variasi tindakan operasi pada KE tergantung pada stadium penyakit. Pada operasi timpanomastoidektomi dinding runtuh, visualisasi lapangan operasi lebih baik sehingga eradikasi kolesteatom lebih baik dan rekurensi lebih renah. Omezzine et al (2013) menyebutkan bahwa sulit menemukan rerata rekurensi pada kasus KE karena kasus tidak cukup sering, namun follow up jangka panjang masih diperlukan. ${ }^{18}$ Menurut Ho et al (2017) rerata follow up yaitu sekitar 5 tahun. ${ }^{28}$

Timpanomastoidektomi dinding runtuh adalah tindakan untuk membuang jaringan yang sakit dari 
rongga mastoid dan ruang telinga tengah, diiringi usaha rekonstruksi tulang pendengaran dan membran timpani. Operasi timpanomastoidektomi dinding runtuh memiliki beberapa kelebihan dan kekurangan (Tabel 4) Pada timpanomastoidektomi dinding runtuh, diusahakan pembersihan total sel-sel mastoid. Mukosa kavum timpani dan sisa tulang pendengaran dipertahankan setelah jaringan patologis dibersihkan. Tuba eustachius tetap dipertahankan. Kemudian kavitas operasi ditutup dengan fasia M. Temporalis. Dilakukan juga rekonstruksi tulang-tulang pendengaran. Teknik operasi yang dilakukan yaitu pasien dioperasi dalam anestesi umum. Insisi yang dilakukan adalah insisi retroaurikuler sehingga didapatkan fascia M. Temporalis yang cukup luas sebagai graft, diperoleh paparan yang luas ke korteks mastoid, terutama ke tip mastoid dan akan diperoleh sudut yang paling baik untuk merendahkan fascial ridge. 24,25

Tabel 4. Keunggulan dan kelemahan timpano mastoidektomi dinding runtuh. ${ }^{25}$

\begin{tabular}{ll}
\hline Teknik Operasi & Dinding Runtuh \\
\hline Fisiologi & Kurang fisiologi \\
Residivitas & Lebih rendah \\
Kesulitan & Lebih rendah \\
Komplikasi & Lebih rendah \\
Perbaikan pendengaran & Lebih rendah \\
Keperluan operasi kedua & Tidak \\
Self cleansing & Sering kontrol \\
Ear mold & Sukar \\
\hline
\end{tabular}

Setelah insisi dan diseksi jaringan lunak, korteks mastoid dipaparkan dengan memasang self retaining retractors. Kemudian dipersiapkan graft fascia M. Temporalis yang akan dipakai untuk menutup kavitas. Diusahakan pembersihan seluruh sel mastoid dengan tetap memperhatikan pembersihan total sel-sel mastoid di sudut sinodura, di daerah segitiga Trautmann, di sekitar kanalis fasialis, di sekitar liang telinga yaitu di prosessus zigomatikus, dan juga di prosessus mastoid, sampai ke ujung mastoid. Sinus timpani harus dibuka sehingga dapat dilihat dengan jelas. Dengan membuang korteks mastoid dan ujung mastoid serta merendahkan facial ridge , akan menyebabkan jaringan lunak di luarnya jatuh (collaps) ke dalam, sehingga luas kavitas operasi akan berkurang. Kavitas operasi ditutup dengan 3 jenis graft. Graft fasia bebas di daerah kavum timpani, graft fasia M. Temporalis di bagian superior dan posterior kavitas mastoid, serta graft kulit liang telinga di bagian bawah kavitas mastoid. Setelah rekonstruksi, seluruh kavum timpani dan sebagian besar kavitas operasi di kavum mastoid ditutup dengan graft fasia dan kulit. Makin lebar graft fasia yang diperoleh akan baik hasilnya karena eratnya hubungannya dengan epitelisasi. Kavitas yang terbentuk juga bisa diobliterasi dengan kartilago tragus dan graft perikondrium, dengan fasia temporal sehingga terbentuk mekanisme self cleansing. Meatoplasti diperlukan sehingga terbentuk aerasi yang adekuat. Meatoplasti merupakan syarat untuk keberhasilan timpanomastoidektomi dinding runtuh. ${ }^{20}$ Meatoplasti dilakukan sehingga liang telinga yang terbentuk cukup besar jadi pinggir bawahnya tidak lebih tinggi dari lantai kavitas pasca operasi. Kemudian dipasang tampon yang lebarnya kira-kira 1 cm dengan panjang secukupnya yang telah diberikan zalf antibiotik, dipasang tidak terlalu padat pada kavitas tersebut. ${ }^{19,25}$

Pada penelitian yang dilakukan oleh Shin et al (2010), keterlibatan dinding inferior yaitu 69\% dan dinding posterior $59 \% .^{8}$ Pada saat operasi dilakukan obliterasi pada defek mastoid, sehingga fungsi selfcleansing masih bisa dilakukan telinga. ${ }^{1}$ Berdasarkan temuan operasi didapatkan membran timpani utuh dan terdapat destruksi pada mastoid. Ini sesuai dengan kriteria Naim bahwa pada stadium IV terdapat destruksi pada mastoid. ${ }^{6}$

Hasil pemeriksaan histopatologi didapatkan potong jaringan yang terdiri atas epitel berlapis gepeng berkeratin, tampak adanya sekuester tulang. Menurut Munoz (2016), Histopatologi dari kolesteatom eksterna adalah terjadinya periosteitis dan sekuester tulang, serta tampak jaringan granulasi. Tampak epitel mengelilingi sekuester tulang. ${ }^{14}$ Menurut Sayless et al (2013), histopatologi kolesteatom eksterna tampak adanya hiperplasia epitel dan periosteitis. ${ }^{1}$

Follow up bulan ketiga, didapatkan tuli konduksi derajat sedang telinga kiri dengan ambang dengar $53,75 \mathrm{~dB}$. Menurut Balfas ini terjadi karena inkus 
sudah diangkat sehingga terjadi diskontuinitas tulang yang menyebabkan kopling osikular akan hilang dan penghantaran energi suara ke telinga dalam hanya melalui kopling akustik. Kopling akustik sekitar $60 \mathrm{~dB}$ lebih kecil dari kopling osikuler sehingga terjadi tuli konduksi sekitar $60 \mathrm{~dB} .{ }^{25}$ Menurut Heywood (2013) pada timpanomastoidektomi dinding runtuh terjadi perubahan resonansi di telinga tengah dan telinga luar karena terbentuk kavitas mastoid dan terjadi penurunan volume pada telinga tengah. ${ }^{29}$

Pada bulan ketiga, liang telinga terlihat masih belum kering, ini terjadi karena diperlukan waktu untuk re-epitelisasi, penelitian yang dilakukan Spronsen dan Geerse (2014) menyimpulkan bahwa diperlukan waktu sekitar 3,6 minggu hingga 25,6 minggu untuk reepitelisasi. ${ }^{23}$ Menurut Persaud et at secara umum, re-epitelisasi terjadi sekitar 10 minggu. $^{7}$ Faktor lain yang mempengaruhi yaitu kanaloplasti yang adekuat sehingga terbentuk KAE yang cukup luas, dengan demikian memfasilitasi perawatan post operatif dan self cleansing kanalis akustikus eksternus. ${ }^{23}$

Penelitian yang dilakukan oleh Yurttas et al (2015) menyebutkan bahwa graft berhasil pada $85,7 \%$ pasien yang dilakukan timpanomastoidektomi dinding runtuh dengan kondisi telinga yang kering lebih dari 3 bulan, sementara itu graft juga berhasil pada $56,5 \%$ pasien dengan kondisi telinga kering kurang dari 3 bulan. ${ }^{22}$ Secara umum pasien dengan prosedur timpanomastoidektomi dinding runtuh perlu kontrol secara rutin untuk mempertahankan epitel pada sisi yang sehat dan mengawasi kemungkinan komplikasi yang akan terjadi. ${ }^{29}$

\section{SIMPULAN}

Operasi timpanomastoidektomi dinding runtuh yang dilakukan pada kasus kolesteatom eksterna dengan perluasan ke kavum mastoid memberikan hasil yang baik, dimana tujuan eradikasi penyakit dan mencegah komplikasi sudah tercapai, namun perbaikan fungsi pendengaran belum maksimal karena tulang pendengaran inkus destruksi. Pada pasien disarankan untuk operasi revisi osikuloplasti telinga kiri. Kontrol secara rutin diperlukan untuk mencegah terjadinya rekurensi.

\section{DAFTAR PUSTAKA}

1. Sayles M, Kamel HA, Fahmy FF. Operative management of external auditory canal cholesteatoma: case series and literature review. The Journal of Laryngology \& Otology. 2013;127: 859-66.

2. Negreiros J, Oliveira HF, Neves CA, Oliveira CA. Case report: External auditory canal cholesteatoma. Int. Adv. Otol. 2009; 5(3):391-93.

3. Owen $\mathrm{HH}$, Rosborg J, Gaihede $\mathrm{M}$. Cholesteatoma of the external ear canal: etiological factors, symptoms and clinical findings in a series of 48 cases. BMC Ear, Nose and Throat Disorders. 2006;9:1-9.

4. Dubach P, Mantokoudis G, Caversaccio M. Ear canal cholesteatoma: meta-analysis of clinical characteristics with update on classification , staging and treatment. Curr Opin Otolaryngol Head Neck Surgery. 2010;18: 369-76.

5. Zanini FD. Ameno ES. Magaldi SO. Lamar RA. Cholesteatoma of external auditory canal: a case report. Rev Bras Otorrhinolaringol. 2005;71(1): 91-3.

6. Ho K, Huang T, Tsai S, Wang H, Chien C, Chang NC. Surgical treatment of external auditory canal cholesteatoma - Ten years of clinical experience. J Int Adv Otol. 2017;13(1):9-13.

7. Persaud RAP, Hajioff D, Thevasagayam, Wareing MJ, Wright A. Keratosis obturans and external ear canal cholesteatoma: how and why we should distinguish between these conditions. Clin. Otolaryngol. 2004;29:577-81.

8. Shin S, Shim JH, Lee H. Classification of external auditory canal cholesteatoma by computed tomography. CEO. 2010;3(1): 24-6.

9. Heilbrun $\mathrm{ME}$, Salzman $\mathrm{KL}$, Glastonbury $\mathrm{CM}$, Harnsberger HR, Kennedy RJ, Shelton C. External Auditory Canal Cholesteatoma: Clinical and Imaging Spectrum. 2003;(April):751-6.

10. Aswani $Y$, Varma R, Achuthan G. Spontaneous external auditory canal cholesteatoma in a young male: Imaging findings and differential diagnoses. Indian Journal of Radiology and Imaging. 2016;26: 237-40. 
11. Topdag, Can E. External ear canal cholesteatoma. ENT otoscopic Clinic. 2010; 89 (9):416-17.

12. Darr EA, Linstrom CJ, York N. Conservative management of advanced external auditory canal cholesteatoma. YMHN. 2010;142(2):278-80.

13. Report C. External auditory canal cholesteatoma mimicking malignancy: a case report. 2005;(111):179-82.

14. Munoz AC. Cholesteatoma of the external auditory canal : A case report. J Otolaryngol ENT. 2016; 5(2): 2-4.

15. Soudry E, Hamzany $Y$, Preis M, Joshua B, Hadar T, Nageris BI. Malignant external otitis: analysis of severe cases. Otolaryngol - Head Neck Surg. 2011;144(5):758-62.

16. Hobson CE, Moy JD, Byers KE, Raz Y, Hirsch BE, McCall AA. Malignant otitis externa: evolving pathogens and implications for diagnosis and treatment. Otolaryngol - Head Neck Surg (United States). 2014;151(1):112-6.

17. Paruthikunnan SM, Ravikanti KC, Ramakrishna N, Shankar, Manipal. High resolution CT of external ear and external auditory canal pathologies: How imaging acts as an adjunct to clinical assessment. ESR. 2015:1-41.

18. Omezzine SJ, Dakkem M, Hmida N Ben, et al. Spontaneous cholesteatoma of the external auditory canal: The utility of CT. Diagn Interv Imaging. 2013;94:438-42.

19. Caponetti G, Lester, Thompson, Pantanowitz. Cholesteatoma. Ear Nose Throat J. 2009;88(11): 1196-98.

20. Sanna M, Sunose H, Mancini F, Russo A, Taibah
A. Middle ear and mastoid microsurgery. New York: Thieme; 2003

21. Artuso A, Nardo WD, Corso ED, Marchese MR, Quaranta N. Canal wall down tympanoplasty surgery with or without ossiculoplasty in cholesteatoma: hearing results. Acta Otorhinolaryngol Ital. 2004; 24: 2-7.

22. Yurttas V, Ural A, Kutluhan A, Bozdemir K. Factors that may affect graft success in tympanoplasty with mastoidectomy. ENT Updates. 2015;5(1):9-12

23. Spronsen VE, Geerse S. Canalplasty in revision radical cavity surgery using a meatal T-skin flap technique. Journal of Otolaryngology-ENT research. 2014;1(1): 1-3

24. Chawla A, Ezhil Bosco JI, Lim TC, Shenoy JN, Krishnan V. Computed tomography features of external auditory canal cholesteatoma: a pictorial review. Curr Probl Diagn Radiol. 2015; 44 (6): 511-6.

25. Balfas HA, Rachman SF, Umar S. Bedah otologi dan bedah neurotologi dasar. Jakarta: EGC; 201726.

27. Ricciardiello F, Cavaliere $M$, Mesolella $M$, lengo M. Notes on the microbiology of cholesteatoma: clinical findings and treatment. Acta Otorhinolaryngol Ital. 2009;29(4):197-02.

28. Ho K, Huang T, Tsai S, Wang H, Chien C, Chang NC. Surgical treatment of external auditory canal cholesteatoma - Ten years of clinical experience. J Int Adv Otol. 2017;13(1): 9-13.

29. Heywood RL. The pros and cons of canal wall up versus canal wall down mastoidectomy for cholesteatoma. The Otorhinolaryngologist. 2013; 6(3):140-43. 